\title{
Libertarianism and circumcision
}

\author{
Patrick Testa, Walter E. Block*
}

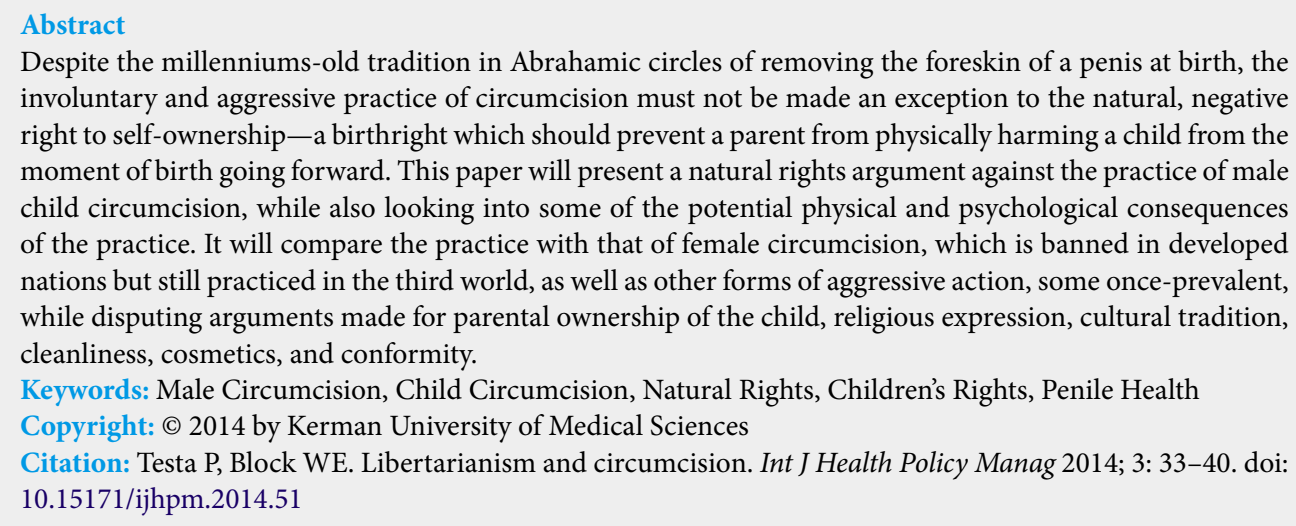

Despite the millenniums-old tradition in Abrahamic circles of removing the foreskin of a penis at birth, the involuntary and aggressive practice of circumcision must not be made an exception to the natural, negative right to self-ownership - a birthright which should prevent a parent from physically harming a child from the moment of birth going forward. This paper will present a natural rights argument against the practice of male child circumcision, while also looking into some of the potential physical and psychological consequences of the practice. It will compare the practice with that of female circumcision, which is banned in developed nations but still practiced in the third world, as well as other forms of aggressive action, some once-prevalent, while disputing arguments made for parental ownership of the child, religious expression, cultural tradition, cleanliness, cosmetics, and conformity.

Keywords: Male Circumcision, Child Circumcision, Natural Rights, Children’s Rights, Penile Health Copyright: @ 2014 by Kerman University of Medical Sciences

Citation: Testa P, Block WE. Libertarianism and circumcision. Int J Health Policy Manag 2014; 3: 33-40. doi: 10.15171/ijhpm.2014.51

Article History:

Received: 28 February 2014

Accepted: 21 May 2014

ePublished: 26 May 2014

\section{Introduction}

Circumcision as a cultural practice is older than written history, and thus there are no certainties when trying to determine its origins; the earliest written accounts date back to pre-Abrahamic times, as with many Judeo-Christian traditions, in Africa (1-5). However, drawing parallels to historical and modern practices, one might theorize the original purpose of male circumcision as being for the reduction of sexual pleasure, not unlike practices of female genital mutilation in several countries today, or one might consider a more symbolic or ceremonial origin $(4,6-8)^{1}$. The following millennia became a back and forth between groups with polarized attitudes toward the practice. Only in recent decades, however, has the practice's prevalence and importance begun to wane in the Western world-and for good reason: it is unethical to partially remove the genitals of an infant, especially given the potential physical and psychological costs of doing so. Male child circumcision, like other once-accepted practices such as slavery, suttee, and arranged marriage before it, is a dated practice unfit for a truly free society and should therefore be abolished in the legal code and from modern religious practices.

In order to help aid this argument, this paper will apply a multidisciplinary analysis. In section II of this paper we consider the ethical implications of circumcision through an understanding of both natural and legal rights, while

1. Many doctors began recommending circumcision in the late 1800 s to prevent children from masturbating. Dr. Kellogg (of cereal brand fame) had this to say about it: "A remedy which is almost always successful in small boys is circumcision, especially when there is any degree of phimosis. The operation should be performed by a surgeon without administering an anesthetic, as the brief pain attending the operation will have a salutary effect upon the mind, especially if it be connected with the idea of punishment... In females, the author has found the application of pure carbolic acid to the clitoris an excellent means of allaying the abnormal excitement" (9). section III will explore some of the potential physical and psychological consequences of neonatal circumcision on the male as an infant and as an adult, relative to some of the oftconsidered benefits. We conclude in section IV.

\section{A natural and legal rights critique}

From a Lockean $(10,11)$ perspective on natural rights and self-ownership ${ }^{2}$, there is no justification for male child circumcision as long as there is no excuse for child abuse. If we acknowledge that our bodies are inherently ours in a natural state (20), then we need not set an arbitrary date to define when parents must start respecting those rights. Despite the legality of neonatal circumcision, Locke was clear in noting that natural rights cannot be surrendered to cultural customs or a social contract; they exist at birth $(21)^{3}$. Furthermore, these rights are negative, not positive, meaning a person is entitled to non-interference in accordance to them-a freedom from coercion. Positive rights refer to entitlement to a good or service (26). Surely no one is entitled to circumcision; most males are not circumcised, and there is a lack of evidence to demonstrate that circumcision is significantly beneficial ${ }^{4}$. Nevertheless, there still exists debate over the relationship

2. For further readings on this topic, see Barnett, 1993, 1995; Blackman, 1995; Flew, 1982; Machan, 1978; Osterfeld, 1983; Rothbard, 2007; Van Dun, 2001 (12-19).

3. For the implications of this statement from the libertarian perspective, see Block, 2004, 2010, 2011, Block and Whitehead, 2005 (22-25).

4. In fact, as we will discuss in sections III and IV, there is evidence to suggest that sequelae from circumcision is enough to deem any medical or psychological benefits insignificant. This is especially true as circumcision rates amongst infants continues to decline, from $85 \%$ of babies in 1985 to $32 \%$ in 2009 , and the bandwagon effect of so-called "prepuce envy" becomes irrelevant (9). Furthermore, the American Academy of Pediatrics specifically states in their policy on circumcision that it is in no way essential to the well-being of a child (27). 
between self-ownership and the rights of children.

More recently, human rights groups and civil libertarian ethicists have made an effort to better define the rights of children and discount "physical treatments [practiced] in the interests of their future welfare" (28). Murray N. Rothbard, for example, dedicated a chapter in his 1982 political philosophy text The Ethics of Liberty on "Children and Rights," in which he aims to better define the notion of self-ownership during childhood. Rothbard notes the grotesquery and hypocrisy of believing in self-ownership while advocating ownership of a child by the parent with which said parent can "murder or torture his or her children"; thus surely any ownership of the child is not received in absolute fee simple (29). He deduces that parental ownership boils down to guardianship so long as the child voluntarily lives at home, in which the child "possesses the right of self-ownership by virtue of being a separate entity and a potential adult" (29). Rothbard (29) concludes that "it must therefore be illegal and a violation of the child's rights for the parent to aggress against his person by mutilating, torturing, [or] murdering him".

Though it supports infant male circumcision practices, the General Assembly of the United Nations has more or less concurred with Rothbard's analysis of children's rights with its inclusion of various articles within the Universal Declaration of Human Rights (30) and the Convention on the Rights of the Child (31). The former declares that no one shall be subjected "to torture... to cruel, inhuman, or degrading treatment" (Article 5) or "to arbitrary inference with his privacy" (Article 12). The latter specifies that a child be considered to be someone below eighteen years of age unless settled otherwise under the law (Article 1), reaffirms the right to freedom of religion for children protected for all other persons (Article 14.1), reaffirms the right to privacy for children protected for all other persons (Article 16), and declares that "State Parties shall take all effective and appropriate measures with a view to abolishing traditional practices" that could harm a child's health, presumably applying to both physical and mental health (Article 24.3). Most importantly, "legislative, administrative, social and educational measures to protect the child from all forms of physical or mental violence, injury or abuse... including sexual abuse, while in the care of parent(s), legal guardian(s) or any other person who has the care of the child," shall be taken to ensure those rights (Article 19.1) ${ }^{5}$. In other words, a child must be protected against coercive acts by a parent or doctor ${ }^{6}$.

From here, the question moves from the rights of the child to the properties of the act of neonatal circumcision-specifically whether or not it can be considered mutilation, a violent act, despite its supposed medical benefits. Stedman's Medical Dictionary (34) defines mutilation as the "disfigurement or injury by removal or destruction of any conspicuous or essential part of the body". The common perception

5. Notably, the United States is one of two nations not to ratify the Convention of the Rights of the Child, although they have signed it, signaling intent to do so (32).

6. For more on how children's rights debate has shifted since Convention on the Rights of the Child from parens patriae, meaning parental ownership of the child, to parental responsibility, see Reynaert et al. (33). of the foreskin is that it is rather inconspicuous and mostly unnecessary, and that circumcision is the removal of a tiny flap of skin, comparable to cutting the umbilical cord. On the contrary, in reality the foreskin accounts for about half of all of the penis' skin-fifteen square inches of skin on an adult male-serving to protect the rest of the penis and enhance sexual pleasure (35-37). It is the removal of significant organ tissue, done without the recommendation of a single major medical association in the world $(38)^{7}$. If the practice is not recommendable and is necessarily physically harmful, then does it not violate the Hippocratic Oath to "first, do no harm?" Surely it violates one of the most "fundamental tenet[s] of international human rights law", guaranteeing to everyone the "right to bodily autonomy and self-determination" $(38,41)$. If there exists any question over whether the child might regret the surgery later in life, then should the decision not be left to the child when he becomes ${ }^{8}$ an adult? In addition to the individual costs borne by those involuntarily subjected to the procedure, the aggregate of all reimbursement costs in the United States, including doctor's fees and repairs for botched circumcisions, is 1.75 billion US dollars each year, a quarter of which is funded by the taxpayers through Medicaid, during a time when healthcare costs are skyrocketing $(38,42,43)$. Currently, right-wing religious groups are crying foul over birth control mandates being an invasion of religious freedom, a negative right, yet there is little difference here as all citizens pay to cover the costs of involuntary male circumcision, often times practiced in the name of God (41).

Fortunately for the newly born, there does exist some legal debate over the practice ${ }^{9}$. Currently, religious groups are protesting a July 2011 court ruling in Germany banning male child circumcision on the grounds that it amounts to bodily harm (44). Additionally, the removal of recommendation by major medical associations and coverage by some health services has begun to significantly reduce prevalence rates in the Western world (45). Still, as the female genital mutilation practices that affect over 130 million girls in the remainder of the world horrify the rest of us, male circumcision mostly 7. The American Academy of Pediatrics' official policy states that data on
potential medical benefits of neonatal circumcision is not sufficient enough
to recommend "routine circumcision for all male newborns" (39). The British
Medical Association states that parental preference is not sufficient justification
for the surgery (40). The Royal Dutch Medical Association's official policy states
that "non-therapeutic circumcision of male minors conflicts with the child's right
to autonomy and physical integrity". Other policy statements read along these
same lines (38).

8. This "impatience" (for want of a better word) extends to the ages at which children are confirmed into the various religions. Would it not be more seemly to ask people to embrace a religion when they reach an age of maturity? The law does not allow children to drink alcohol, or drive a car, or marry without parental consent, or be free of statutory rape victimization until the ages of 16 , or 18 or 21 or thereabouts, depending upon jurisdiction. No one can become president of the United States until he reaches the age of 35. Is it too much to hope for that such rational arrangements can be made for age of consent to religious belief, and the decision to engage in circumcision?

9. The practice of adult circumcision in itself is not unethical but rather the practice of involuntary neonatal circumcision. Without any means to give consent, the health of the infant, both physical and psychological, cannot and should not be gambled with for the sake of cosmetics, tradition, or religion or conformity. 
escapes the same outrage $(46)^{10}$. For some, the practice is permissible under the guise of tolerating multiculturalism, the significance of which confers "special rights, or exemptions from rights-based prohibitions" (47). The errors in making this exception should be excruciatingly obvious ${ }^{11}$. For others, it is simply tradition-a normal, even non-religious medical operation $(35,49)^{12}$. But it seems the real loophole, and the roadblock in the way of minimizing the tradition, is medical, as most common law jurisdictions treat "any application of force, no matter how slight, [as] prima facie an assault", with exceptions made for medical treatment (45). But is the purpose of the law to promote the "greater good" or to protect the rights of individuals? If it is the latter, then coercive acts, medical or not, have no place being protected by the legal code. Nevertheless, if the "greater good"13 must prevail over the individual, can the potential benefits justify the potential costs of male child circumcision? The evidence is weak.

\section{A consequentialist critique}

We already know that medical associations do not recommend neonatal circumcisions, but neither do they recommend against them. Of course, this can be attributed to the fact that they are taking a medical standpoint and not an ethicsbased one, but even so, there are many arguments in favor of keeping the practice from being banned outright. Some of the objections used as evidence defending infant circumcision of boys include the risk of phimosis, a greater chance of infection under the foreskin, a greater risk of Urinary Tract Infection (UTI), and most popularly a significantly heightened risk of contracting sexually transmitted infections such as HIV. In reality, these claims are refutable or insignificant. And on the contrary, circumcision itself comes with major medical risks. A common misconception about the foreskin is that it is always retractable; alas, only half of all boys by age ten have a prepuce in the retractile state. So exists the perpetuated myth of child phimosis, which means that the foreskin cannot retract. A non-retractile foreskin is not necessarily a problem at all, as it is cleaned by urine, which is sterile (52). But a nonretractile foreskin in a young child is entirely normal, and Premature Forcible Foreskin Retraction is generally the result of a physician pushing back the underdeveloped prepuce in order to reduce infection $(52,53)$. Instead, this procedure may leave an infant with greater risk of infection, as well as scarring and sexual dysfunction down the line (52). Once the foreskin does retract on its own, a simple rinse with soap is sufficient to clean that body part (54). If it eventually becomes apparent that phimosis is pathologic in nature rather than physiologic,

10. Should not both sexes be allowed to keep its genitals in their entirety? J. Steven Svoboda asks: "What could more clearly coincide with common sense than the principle that males as well as females should, in the absence of extremely compelling and exceptional reasons militating otherwise, retain the genitals that are their birthright?" (48)

11. What about slavery, sacrifice, suttee, corporal punishment, etc.?

12. Franz Boas, pioneer of American anthropology, had a point when he observed how ways of thinking that dominate cultural life tend to persist despite major geographical, industrial, or scientific transformations (50). Richard Dawkins coined the term "meme" to describe this non-genetic phenomenon of imitation, using circumcision as an example (51).

13. Never mind trying to determine how one would define such a thing. circumcision exists as an option. However, other surgical and non-surgical treatments exist with high success rates, with lower cost and lesser morbidities than circumcision, such as the use of steroid topical cream; nevertheless, most cases of phimosis are physiologic in nature, and understanding the distinction between these types of phimosis can prevent overdiagnosis and unnecessary circumcision, as gentle retraction and normal washing over time can serve to treat physiologic phimosis (55-57). Furthermore, penises that have not been forcibly retracted are statistically no more prone to UTIs than circumcised penises, and overall an uncircumcised male is less than $1 \%$ more likely to get a UTI than a circumcised male, with the highest prevalence seen at less than one year of age $(27,54)$. One study concludes that it would take 195 circumcisions to prevent one UTI (58). Regardless, a UTI is easily treated with antibiotics, and circumcision need not play a role in preventing them $(54)^{14}$. Ultimately, there is little significant evidence to "affirm the association between circumcision status and optimum penile hygiene" (27).

Arguably the most cited evidence that a circumcised state is preferable is relatively recent, originating during the HIV/AIDS crisis in the 1980s. In 2007, the World Health Organization and the United Nations published a report highlighting a correlation between a lack of circumcision and high HIV rates, specifically in Eastern and Southern Africa. The report concludes, "there is substantial evidence that male circumcision protects against... UTIs, syphilis, chancroid and invasive penile cancer, as well as HIV" (59) ${ }^{15}$. Midway through the report, it is clarified that, as we have already observed, neonatal circumcision is not recommended by national pediatric societies in the industrialized world because the risks appear to outweigh any benefits (59). Meanwhile, just prior, the report states that "poor penile hygiene may contribute to the risk of infections among uncircumcised men", with significantly higher HIV rates reported in uncircumcised men with penile wetness under the foreskin two weeks before treatment than the circumcised control group; however there is little difference in HIV rates between uncircumcised and circumcised men without penile wetness (59). In other words, the report paints a clear difference between hygiene geographically in correlation with HIV rates, without clearly defining the magnitude of the lack of circumcision as a variable. The report also notes that there is a high-risk of circumcision complication in high-risk HIV countries, including wound infection, severe hemorrhage, swelling, and urine retention, further indicating that the problem at hand is not so much a lack of circumcision but a lack of general hygiene, as well as demonstrating some of the risks of the procedure $(59,60)^{16}$. Furthermore, the report

\footnotetext{
14. Suppose getting rid of the foreskin was justifiable under the argument that it would slightly diminish UTI rates. Should we likewise eliminate cars since that would drastically diminish road deaths?

15. It must be noted that the report also strongly advised against unhygienic settings and inexperienced providers due to serious sequelae. It also aimed to increase access to "safe, voluntary and affordable... adult male circumcision" (59). The language is praiseworthy, but the data is debatable.

16. This is not to say that the circumcision of adult males in undeveloped countries has no use in combating the spread of HIV. Randomized trials
} 
chooses to ignore examples of countries where circumcision and HIV are both extremely common, such as Cameroon, Gabon, Nigeria, and Kenya, as well as those where neither is common, such as Cuba, Mongolia, Mexico, and China ${ }^{17}$. Additionally, it does not acknowledge methods other than female-to-male intercourse in contributing to the spread of HIV, including non-sex, male-to-female, and homosexual transmission ${ }^{18}$. Meanwhile, the underlying issues of cleanliness and lack of prophylactic protection go mostly unchecked. One 2008 study found "free condoms" missions in SubSaharan Africa to be more effective in preventing the spread of HIV than circumcision, protecting both men and women ${ }^{19}$, and found them at least 95 times more cost effective (67). Indeed, instead of publicizing and editorializing about how circumcision is a preventative measure and thereby possibly disincentivizing further expansion of condom use in lowincome countries, focus could be shifted to developing better hygiene, more prominent condom usage, and well-rounded sex education. For adults that choose to, circumcision could remain an option.

Ultimately, it is fallacious to imply something is "worth it" because it might save lives. Does the very real risk of breast cancer warrant removing the breast buds at birth? Whereas the lifetime risk that a woman will get breast cancer is about $12 \%$, the risk of acquiring HIV is less than $2 \%$, and near zero with condom use (54). Though the studies suggest circumcision can prevent or delay contraction of HIV to some degree, the data ultimately amounts to a large percentage decrease over a trivial base, looking at a significantly relative risk reduction for what is actually minor in absolute risk reduction ${ }^{20}$. And what good is a preventative health measure if the potential costs outweigh the benefits? When the costs are confronted, the argument for circumcision as a preventative health measure quickly falls away.

The act of circumcision involves the removal of substantial tissue, leaving the glans exposed and making it susceptible to infection and major blood loss. This process is comparable in terms of pain experienced to "ripping a fingernail from the quick" (45). Thousands of nerve endings important to sexual pleasure are removed, and the once-protected glans

by Auvert et al. (61), Gray et al. (62), and Bailey et al. (63) support offering circumcisions to men as means to prevent the spread of HIV; however, this need not apply to infant males. Bailey et al. (63) sums up: "Where appropriate, voluntary, safe, and affordable circumcision services should be integrated with other HIV preventive interventions and provided as expeditiously as possible."

17. Cameroon has $93 \%$ circumcision rate and $5.1 \%$ HIV rate, Gabon has $93 \%$ circumcision rate and $5.9 \%$ HIV rate, Nigeria has $81 \%$ circumcision rate and $3.10 \%$ HIV rate, and Kenya has $84 \%$ circumcision rate and $6.7 \%$ HIV rate. Cuba, Mongolia, Mexico, and China all have circumcision rates $<20 \%$, while Cuba has $0.1 \%$ HIV rate, Mongolia has $0.1 \%$ HIV rate, Mexico has $0.3 \%$ HIV rate, and China has $0.1 \%$ HIV rate $(59,64,65)$. Similarly, at the peak of the AIDS epidemic, the United States was at peak circumcision levels (54).

18. The risk of STD is possibly "more strongly related to sexual practices than to the presence of a foreskin" $(60,66)$.

19. This is important, considering $61 \%$ of adults with AIDS in Sub-Saharan Africa are women.

20. "Limitations to the studies from which... risk ratios [for the uncircumcised in Africa when it comes to HIVIAIDS] are [largely] derived include poor sampling, a low rate of acquiring the disease, and not controlling for confounders such as the number of sexual partners or other sexual practices". Results are statistically negligible and "probably not generalizable to the U.S. population" $(60,66,68)$. quickly becomes hardened and dried out, furthering the desensitization process, creating difficulties in the orgasm process, and impeding the sexual intensity of intercourse for both the circumcised male and the receiving female (45). The pain involved with the circumcision process as experienced by newborns is difficult to gauge without a satisfactory primary source but can be understood by analyzing the behavior of the infant. One such analysis found a positive correlation between duration, loudness, and pitch of crying and the invasiveness of the surgery, as well as intensified facial expression including lowered brow, tightened eyes, excitability in the spinal cord, an open mouth, and a cupped tongue (69). Another study measured the effects of anesthesia during circumcision on infant reaction and included a control group without any anesthesia at all. The study ended, however, when the doctors decided the pain was too great for it to be considered ethical, as some babies began choking and one had a seizure (36). Nevertheless, in real practices only $45 \%$ of doctors use any anesthesia, as such procedures can take up to thirty minutes while the removal of the foreskin itself is quite brief (36). Total anesthesia, which would put an infant to sleep during the surgery, is not available, and the next best thing, the dorsal penile nerve block, still leaves the underside of the penis receptive (36).

Aside from the short-term side effects, circumcision can do major damage in the long term, with complication rates during the first three years alone affecting about 1 in 50 of those treated in this manner. These complications include meatal stenosis, which is the narrowing of the urethra; adhesions involving remnants of the foreskin healing to the head and requiring removal; "buried penis", in which too much skin is removed and the penis cannot comfortably become erect, leading to tears in the skin and/or erectile dysfunction; serious infection of the glans, which may require the denuding of the penis, skin transplants from other areas of the body, and/or complete removal of the scrotum; or even death; over 100 newborns die each year in the US alone from blood loss or infection from circumcision $(36,45)^{21}$. Indeed, on a physical level the potential consequences are great. Meanwhile, a growing amount of evidence suggests that the intense pain felt by the newborn male during circumcision, as well as the loss of what would be about half of his penile tissue as a mature adult, has immense long-term adverse effects on his psychological well-being $(36,37,58,69-73)$. The official manual of mental disorders as published by the American Psychiatric Association describes a traumatic event as one "that is beyond human experience, such as assault (sexual or physical), torture, and a threat to one's physical integrity", regardless of intent or purpose (73). This is especially true at a young age and if the circumcision procedure is as most are and lacks anesthesia. The body keeps a record of its experiences in order to better survive, and

21. In one particular case in Seattle, a gangrene growth from the circumcision wound required the removal of the scrotum and excised skin from the infant's entire core section in order to save his life. In another case, the botched circumcision of a Canadian man ended in an inappropriate gender reassignment that eventually led to his suicide. A third case in Britain resulted in one appalled man winning 800 thousand pounds after he needed an operation to repair defects resulting from the circumcision (45). 
neonatal circumcision involves rewiring the brain despite not preserving an explicit memory (36).

One particular 2000 study based in the Philippines, where circumcision is customary and a requirement of the culture, sought to test the suggested link between involuntary circumcision and Post-Traumatic Stress Disorder (PTSD) ${ }^{22}$. In this case, the circumcision procedure is performed in preadolescence, and only boys without any pre-existing signs of PTSD were included in the study, allowing the traumatic nature of circumcision to be analyzed ${ }^{23}$. The survey targeted two groups of participants, including those undergoing medical circumcision, which involves a screening to confirm that the foreskin is retractile and is performed with mild anesthesia, and those undergoing ritual circumcision, which features no such screening and completely lacks anesthesia. Both types of circumcision are considered culturally valid. Circumcisions were followed up with a questionnaire relating to perception of the procedure and pain level, as well as a questionnaire to test 17 items reflecting symptoms of $\mathrm{PTSD}^{24}$. Analysis of these results concluded that $69 \%$ of the 505 males circumcised ritually and 51\% of the 1072 circumcised medically "fulfilled the DSM-IV criteria for a diagnosis of PTSD", while participant age, time elapsed since the procedure, and perception of circumcision "were not significant predictors for PTSD development" (74).

Another recent study, published in the International Journal of Epidemiology in 2011, analyzed the connection between neonatal circumcision and the existence of intimacy problems related to psychological and/or physical trauma amongst Danish men. The study included a survey of 5552 circumcised and uncircumcised men, in which the former presented an almost threefold increase when compared to the latter, from $4 \%$ to $11 \%$, in the presentation of frequent anorgasmia. The same study also noted sexual difficulties present in women with circumcised partners when compared to those with uncircumcised partners, including an increase of more than one third in frequent anorgasmia, an increase of more than one third in unfulfilled sexual need, and a fourfold increase in dyspareunia, or painful intercourse $(71)^{25}$. A similar

22. Ramos and Boyle reason, "A child is unable to withhold consent, cannot control what happens to his body, and is unlikely to have enough information... Factors that may predispose a person to... PTSD include feelings of powerlessness and loss of control, lack of consent/lack of information... and the experience of pain", often of a sexual nature (74).

23. A total of 3253 boys from five different schools in the Batangas province of the Philippines were contacted for inclusion in the study, and 1577 were deemed to be lacking prior trauma and signs of PTSD. Parents or guardians approved all participation by minors in the study.

24. The PTSD Questionnaire was "adapted from the Watson et al. PTSD-I interview rating scale... [which] was developed to meet four specific criteria: 1) close specification of Diagnostic and Statistical Manual of Mental Disorders, Fourth Edition (DSM-IV) standards, 2) binary present/absent outputs in each symptom and entire syndrome, 3) can be administered by trained subprofessionals, 4) substantial reliability and validity. Participants answered each question on a Likert rating scale from 1 ("no, never") to 7 ("extremely, always"). This study considered a 4 ("somewhat, commonly") sufficient to meet the relevant DSM symptom criterion" (74).

25. Specifically, differences in spouses of circumcised men compared to those of uncircumcised men: anorgasmia (19\% vs. $14 \%$ ); incomplete sexual needs fulfillment (38\% vs. $28 \%)$; and dyspareunia $(12 \%$ vs. $3 \%)$. Frequent sexual function difficulties overall amongst women were $31 \%$ (circumcised partners) compared to $22 \%$ (uncircumcised partners) (71). preliminary poll conducted from 1993 to 1996 and published in 1999 in the British Journal of Urology International surveyed 546 circumcised American men, 94\% of whom were circumcised in infancy; $61 \%$ of respondents reported sensory deficit leading to sexual dysfunction, including erectile problems, orgasm difficulties, and/or anorgasmia, and 40\% reported extraordinary stimulation required for orgasm. The same poll revealed amongst at least half of participants feelings of mutilation, resentment, and sexual inferiority (70). Ultimately, the difficulties of meeting the conditions of ceteris paribus in analyzing the long-term consequences of male child circumcision, as well as the impossibility of receiving consent or feedback from the infant, result in a knowledge problem of which the optimal solution to the circumcision debate is to simply wait a few years and allow the individual to choose for himself. Under this approach, any sought after benefits of circumcision can be achieved without risking subjecting the vast potential physical and psychological costs onto the infant male.

\section{Conclusion}

The reality of the debate on neonatal circumcision is that it hardly exists at all. Most male Americans grew up in an era where nearly everyone was circumcised; to be uncircumcised was considered unusual. Even for many of those who disdain violence and the struggle to retain archaic social norms, it is almost as if circumcision is a topic off-limits to debateperhaps out of denial or an appealing sense of conformity. But underneath the guise of culture, neonatal circumcision is a violation of the right to bodily integrity, an overreach of religious freedom, and a coercive act on the most helpless of us all.

Fortunately, the circumcision fad of the last century appears to be waning ${ }^{26}$, at least in the West, as newborn circumcision rates dropped from between $65 \%$ to $85 \%$ of babies in the early 1980 s to between $32 \%$ and $57 \%$ in the last half-decade $(9,75,76)^{27}$. We can explain to our children how we once "thought we had to cut off the foreskin, but now we know better", and sweep away fallacious justifications about tradition, cosmetics, conformity, and the "greater good", as well as statistically weak rationales regarding UTIs and hygiene (9). The culture changed in a couple of centuries to shun slavery, become tolerant of interracial marriage, and allow and even encourage women to enter the workforce. Like those traditions before it, the antiquation of male child circumcision alone should be reason enough to give it a second look.

The crucial point is that we as a society can have our cake and eat it too in this regard. All we need do is not eliminate circumcision but rather postpone it. Instead of imposing it on helpless babies, too weak and immature to object to this invasive medical procedure, adults can choose for themselves whether or not to avail themselves of circumcision. Those convinced of its benefits would be free to do so; others need not. Friedman and Friedman (77) is entitled Free to Choose;

26. A case in point may be found here: http://news.yahoo.com/german-courtoutlaws-religious-circumcision-172728400.html

27. Although in seeking this data it became clear that estimated rates are difficult to produce and vary wildly, especially geographically. 
that phrase certainly applies to the present circumstance. It is no less than a form of child abuse to enforce upon children so momentous and irreversible a decision. Why not allow them to choose for themselves when they arrive at an age at which they are able to do so based on their own free will?

We have mentioned numerous drawbacks to circumcision. One conclusion we draw from this evidence is that it would be unwise even for an adult to engage in this procedure. That decision, of course, in a free society, would be up to him, and him alone. The more important conclusion that follows from these considerations is that it is a particularly "cruel and (all too) usual" form of punishment to impose upon an innocent male child ${ }^{28}$.

We claim that libertarianism proscribes the use of violence against innocent people. Babies are innocent; this cannot be denied. Nor will anyone quarrel with the view that circumcision is a violent invasive act, when not undertaken volitionally. Newborns lack the volition to make any such choice for themselves. Hence, it is unjustified, according to libertarian principles. This conclusion does not at all apply to adults who decide to undergo this type of surgery on a voluntary basis. For consenting adults, libertarianism does not at all proscribe circumcision.

\section{Ethical issues}

Not applicable.

\section{Competing interests}

Authors declare that they have no competing interests.

Authors' contributions

PT and WEB contributed equally to the drafting and revising of the manuscript and have read and approved the final version.

Authors' affiliations

Joseph A. Butt, S.J. College of Business, Loyola University, New Orleans, USA.

\section{References}

1. Darby RJ. Medical history and medical practice: persistent myths about the foreskin. Med J Aust 2003; 178: 178-9.

2. Darby RJ. The riddle of the sands: circumcision, history, and myth. N Z Med J 2005; 118: U1564.

3. Gollaher D. Circumcision: a history of the world's most controversial surgery. New York: Basic Books; 2000.

4. Marck J. Aspects of male circumcision in sub-equatorial African culture history. Health Transit Review 1997; 7: 337-60.

5. West JA. The traveler's key to ancient Egypt: a guide to the sacred places of ancient Egypt. Wheaton: Theosophical Publishing House; 1995. p. 187.

6. The Circumcision Information and Resource Pages [homepage on the Internet]. [updated 2011 August 28]. History of Circumcision. Available from: http://www.cirp.org/library/history

7. Silverman EK. The Cut of Wholeness: Psychoanalytic Interpretations of Biblical Circumcision. In: Mark EW, editor. The Covenant of Circumcision. Hanover and London: Brandeis University Press; 2003. pp. 43-57.

8. Glick NS. Zipporah and the Bridegroom of Blood: Searching

28. It would take us too far afield from the focus of this paper to determine the age of consent at which point a male could properly make this decision. For our present purposes we accept as a starting point any of the ages at which people are allowed to vote, to drink alcohol, to drive, to engage in contracts, etc. But clearly, the eighth day of age, at which point in the Jewish tradition the bris occurs (http://www.torahview.com/bris/html/the_bris.html), is far too young. for the Antecedents of Jewish Circumcision. In: Denniston GC, Gallo PG, Hodges FM, Milos MF, Viviani F, editors. Bodily Integrity and the Politics of Circumcision. New York: Springer; 2006. p. 37-48.

9. Narvaez D. Circumcision: Social, Sexual, Psychological Realities. Psychology Today [serial on the Internet]. 2011 September 18. Available from: http://www.psychologytoday. com/blog/moral-landscapes/201109/circumcision-social-sexualpsychological-realities

10. Locke J. An Essay Concerning the True Origin, Extent and End of Civil Government. In: Barker E, editor. Social Contract. New York: Oxford University Press; 1948.

11. Locke J. Second Treatise of Civil Government. Chicago: Henry Regnery; 1955.

12. Barnett RE. The Intersection of Natural Rights and Positive Constitutional Law. Connecticut Law Review 1993; 25: 853-68.

13. Barnett RE. Getting Normative, the Role of Natural Rights in Constitutional Adjudication. Constitutional Commentary 1995; 12: 93-122. doi: 10.1093/acprof:oso/9780199243006.003.0008

14. Blackman RJ. There is There There: Defending the Defenseless with Procedural Natural Law. Arizona Law Review 1995; 37 : 285-353.

15. Flew A. Could there be Universal Natural Rights? The Journal of Libertarian Studies 1982; 6: 277-88.

16. Machan T. Against nonlibertarian natural rights. The Journal of Libertarian Studies 1978; 2: 233-8.

17. Osterfeld D. The Natural Rights Debate: A Comment on a Reply. The Journal of Libertarian Studies 1983; 2: 101-13.

18. Rothbard MN. Introduction to Natural Law. Mises Daily [serial on the Internet]. 2007. Available from: https://mises.org/daily/2426

19. Van Dun F. Human dignity: reason or desire? Journal of Libertarian Studies 2001; 15: 1-28.

20. Kinsella SN. 2006. How we come to own ourselves. Mises Daily [serial on the Internet]. 2006 September 7. Available from: http:// www.mises.org/story/2291

21. Forde S. John Locke and the Natural Law and Natural Rights Tradition. Natural Law, Natural Rights, and American Constitutionalism [serial on the Internet]. 2012. Available from: http://www.nlnrac.org/earlymodern/locke

22. Block WE. Libertarianism, Positive Obligations and Property Abandonment: Children's Rights. International Journal of Social Economics 2004; 31: 275-86. doi: 10.1108/03068290410518256

23. Block WE. A libertarian perspective on the stem cell debate: compromising the uncompromisible. J Med Philos 2010; 35: 429-48. doi: 10.1093/jmp/jhq033

24. Block WE. Terri Schiavo: A Libertarian Analysis. Journal of Libertarian Studies 2011; 22: 527-36.

25. Block WE, Whitehead R. Compromising the Uncompromisable: A Private Property Rights Approach to Resolving the Abortion Controversy. Appalachian Law Review 2005; 4: 1-45.

26. Rights. Stanford Encyclopedia of Philosophy. 2011 July 2. Available from: http://plato.stanford.edu/entries/rights

27. Lannon CM, Bailey AND, Fleischman AR, Kaplan GW, Shoemaker CT, Swanson JT, et al. American Academy of Pediatrics: Circumcision Policy Statement. Pediatrics 1999; 103: 686-93. doi: 10.1542/peds.103.3.686

28. Kukathas C. Two Constructions of Libertarianism [internet]. 2001. Available from: http://mises.org/journals/scholar/libertarian.pdf

29. Rothbard MN. The Ethics of Liberty. New York and London: New York University Press; 1998.

30. Universal Declaration of Human Rights [internet]. 1948. The United Nations. Available from: http://www.un.org/en/documents/ udhr

31. Convention On the Rights of the Child. 1989. The United Nations. Availablefrom: http://www2.ohchr.org/english/law/pdf/crc.pdf 
32. Shah A. Rights of the Child. Global Issues [serial on the Internet]. 2003 September 27. Available from: http://www.globalissues.org/ article/152/rights-of-the-child

33. Reynaert D, Bouverne-de-Bie M, Vandevelde S. A review of children's rights literature since the adoption of the United Nations Convention on the Rights of the Child. Childhood 2009; 16: 518-34. doi: 10.1177/0907568209344270

34. Stedman's Medical Dictionary. Baltimore: William \& Wilkins Publishers; 1990. p. 1009.

35. Glick LB. Marked in Your Flesh. New York: Oxford University Press; 2005

36. Narvaez D. Myths about Circumcision You Likely Believe. Psychology Today [serial on the Internet]. 2011 September 11. Available from: http://www.psychologytoday.com/blog/morallandscapes/201109/myths-about-circumcision-you-likely-believe

37. Denniston GC. An Epidemic of Circumcision. National Organization of Circumcision Information Resource Centers [serial on the Internet]. 1994. Available from: http://www.nocirc. org/symposia/third/denniston3.html

38. Narvaez D. Circumcision Ethics and Economics. Psychology Today [serial on the Internet]. 2011 September 25. Available from: http://www.psychologytoday.com/blog/moral-landscapes/201109/ circumcision-ethics-and-economics

39. Atendido MCM. The 2012 AAP Policy Statement: Skinning the New Policy on Circumcision [internet]. 2013. Available from: http://www.law.uh.edu/healthlaw/perspectives/2013/Atendio The $\% 202012 \% 20$ AAP\%20Policy\%20Statement_Skinning $\% 20$ the $\% 20 \mathrm{New} \% 20 \mathrm{Policy} \% 20$ on\%20Circumcision.pdf

40. BMA Medical Ethics Committee. The Law \& Ethics of Male Circumcision - Guidance For Doctors [internet]. 2006 June 15. Available from: http://www.cirp.org/library/statements/bma2003

41. Denniston GC. Human Rights Advances in the United States. In: Denniston GC, Gallo PG, Hodges FM, Milos MF, Viviani F, editors. Bodily Integrity and the Politics of Circumcision. New York: Springer; 2006. p. 189-202.

42. Craig A, Bollinger D. Of Waste and Want: A Nationwide Survey of Medicaid Funding for Medically Unnecessary, Non-Therapeutic Circumcision. In: Denniston GC, Gallo PG, Hodges FM, Milos MF, Viviani F, editors. Bodily Integrity and the Politics of Circumcision. New York: Springer; 2006. p. 233-46.

43. Geisheker JV. Toward Regulation of Non-Therapeutic Genital Surgeries Upon Minors: A Preliminary Legal Strategy. In: Denniston GC, Gallo PG, Hodges FM, Milos MF, Viviani F, editors. Bodily Integrity and the Politics of Circumcision. New York: Springer; 2006. p. 203-18.

44. Evans S. German Circumcision Ban: Is It a Parent's Right to Choose. BBC News [serial on the internet]. 2012 July 12. Available from: http://www.bbc.co.uk/news/magazine-18793842

45. Boyle GJ, Svoboda JS, Price CP, Turner JN. Circumcision of Healthy Boys: Criminal Assault? J Law Med 2000; 7: 301-10.

46. Whitehorn J, Ayonrinde O, Maingay S. Female Genital Mutilation: Cultural and Psychological Implications. Sex Relation Ther 2002; 17: 161-70. doi: 10.1080/14681990220121275

47. McKinnon C. Toleration. London and New York: Routledge; 2006.

48. Svoboda JS. Genital Integrity and Gender Equity. In: Denniston GC, Gallo PG, Hodges FM, Milos MF, Viviani F, editors. Bodily Integrity and the Politics of Circumcision. New York: Springer; 2006. p. 149-64.

49. Erez S, Tabory E. Circumscribed Circumcision: The Motivations and Identities of Israeli Parents Who Choose Not to Circumcise Their Sons. In: Mark EW, editor. The Covenant of Circumcision. Hanover and London: Brandeis University Press; 2003. p. 16176.

50. Abusharaf RM. Virtuous Cuts: Female Genital Circumcision in an African Ontology. In: Scott JW, Keates D, editors. Going Public: Feminism and the Shifting Boundaries of the Private Sphere. Urbana and Champaign: University of Illinois Press; 2004. p. 201-24.

51. Young H. Circumcision as a Memeplex. In: Denniston GC, Gallo PG, Hodges FM, Milos MF, Viviani F, editors. Bodily Integrity and the Politics of Circumcision. New York: Springer; 2006. p. 1-16.

52. Geisheker JV. What Is the Greatest Danger for an Uncircumcised Boy? Psychology Today [serial on the internet]. 2011 October 23. Available from: http://www.psychologytoday.com/blog/morallandscapes/201110/what-is-the-greatest-danger-uncircumcisedboy

53. Llewellyn DJ. Strategies for Litigation. In: Denniston GC, Gallo PG, Hodges FM, Milos MF, Viviani F, editors. Bodily Integrity and the Politics of Circumcision. New York: Springer; 2006. p. 219-32.

54. Narvaez D. More Circumcision Myths You May Believe: Hygiene and STDs. Psychology Today [serial on the internet]. 2011 September 13. Available from: http://www.psychologytoday.com/ blog/moral-landscapes/201109/more-circumcision-myths-youmay-believe-hygiene-and-stds

55. Dewan PA, Tieu HC, Chieng BS. Phimosis: is circumcision necessary. J Paediatr Child Health 1996; 32: 285-9. doi: 10.1111/j.1440-1754.1996.tb02554.x

56. McGregor TB, Pike JG, Leonard MP. Pathologic and physiologic phimosis: approach to the phimotic foreskin. Can Fam Physician 2007; 53: 445-8.

57. Steadman B, Ellsworth P. To circ or not to circ: indications, risks, and alternatives to circumcision in the pediatric population with phimosis. Urol Nurs 2006; 26: 181-94.

58. Learman LA. Neonatal Circumcision: A Dispassionate Analysis. Clin Obstet Gynecol 1999; 42: 849-59. doi: 10.1097/00003081199912000-00011

59. World Health Organization and Joint United Nations Programme on HIV/AID. Male Circumcision: Global Trends and Determinants of Prevalence, Safety and Acceptability [internet]. 2007. Available from: http://whqlibdoc.who.int/ publications/2007/9789241596169_eng.pdf

60. American Academy of Family Physicians. Circumcision: Position Paper on Neonatal Circumcision. 2002. Available from: http:// www.cirp.org/library/statements/aafp2002/

61. Auvert B, Taljaard D, Lagarde E, Sobngwi-Tambekou J, Sitta R, Puren A. Randomized, Controlled Intervention Trial of Male Circumcision for Reduction of HIV Infection risk: The ANRS 1265 Trial. PLoS Med 2005; 2: e298. doi: 10.1371/journal. pmed.0020298

62. Gray R, Kigozi G, Serwadda D, Makumbi F, Watya S, Nalugoda $F$, et al. Male circumcision for HIV prevention in men in Rakai, Uganda: a randomised trial. Lancet 2007; 369: 657-66. doi: 10.1016/s0140-6736(07)60313-4

63. Bailey RC, Moses S, Parker CB, Agot K, Maclean I, Krieger $\mathrm{JN}$, et al. Male circumcision for HIV prevention in young men in Kisumu, Kenya: a randomised controlled trial. Lancet 2007; 369: 643-56. doi: 10.1016/s0140-6736(07)60312-2

64. The World Factbook. Central Intelligence Agency [internet]. 2011. Available from: https://www.cia.gov/library/publications/ the-world-factbook

65. Williams BG, Lloyd-Smith JO, Gouws E, Hankins C, Getz WM, Hargrove J, et al. The potential impact of male circumcision on HIV in Sub-Saharan Africa. PLoS Med 2006; 3: e262. doi: 10.1371/journal.pmed.0030262

66. Laumann EO, Masi CM, Zuckerman EW. Circumcision in the United States: prevalence, prophylactic effects, and sexual practice. JAMA 1997; 277: 1052-7. doi: 10.1001/ jama.277.13.1052 
67. McAllister RG, Travis JW, Bollinger D, Rutiser C, Veeraraghavan Sundar. The Cost to Circumcise Africa. International Journal of Men's Health 2008; 7: 307-16. doi: 10.3149/jmh.0703.307

68. Van Howe RS. A Cost-Utility Analysis of Neonatal Circumcision. Med Decis Making 2004; 24: 584-601. doi: $10.1177 / 0272989 \times 04271039$

69. Boyle GJ, Goldman R, Svoboda JS, Fernandez E. 1 May 2002. Male Circumcision: Pain Trauma and Psychosexual Sequelae. J Health Psychol 2002; 7: 329-43. doi: $10.1177 / 1359105302007003225$

70. Hammond T. A preliminary poll of men circumcised in infancy or childhood. BJU Int 1999; 83: 85-92. doi: 10.1046/j.1464410x.1999.0830s1085.x

71. Frisch M, Lindholm M, Grønbæk M. Male circumcision and sexual function in men and women: a survey-based, crosssectional study in Denmark. Int J Epidemiol 2011; 40: 1367-81. doi: $10.1093 /$ ije/dyr104

72. Aydur E, Gungor S, Ceyhan ST, Taiimaz L, Baser I. Effects of Childhood Circumcision Age on Adult Male Sexual Functions. Int
J Impot Res 2007; 19: 424-31. doi: 10.1038/sj.ijir.3901545

73. Goldman R. The Psychological Impact of Circumcision. BJU Int 1999; 83: 93-102. doi: 10.1046/j.1464-410x.1999.0830s1093.x

74. Ramos S, Boyle GJ. Ritual and Medical Circumcision Among Filipino Boys: Evidence of Post-traumatic Stress Disorder. Humanities \& Social Sciences Papers 2000. Available from: http://epublications.bond.edu.au/hss_pubs/114/

75. Zhang X, Shinde S, Kilmarx PH, Chen RT, Cox S, Warner L, et al. Trends in In-Hospital Newborn Male Circumcision, United States, 1999-2010. Centers for Disease Control and Prevention; 2011. Available from: http://www.cdc.gov/mmwr/preview/ mmwrhtml/mm6034a4.htm

76. Kozak LJ, Lees KA, DeFrances CJ. National Hospital Discharge Survey: 2003 annual summary with detailed diagnosis and procedure data. Vital Health Statistics, 2006; 13. Available from: http://www.cdc.gov/nchs/data/series/sr_13/sr13_160.pdf

77. Friedman M. Free to Choose. New York: Harcourt, Brace, Jovanovich; 1980. 